\title{
Agronomic performance of lettuce subjected to green manure with different leguminous species
}

\author{
José J. A. Sarmento ${ }^{1}$, José J. F. dos Santos ${ }^{1}$, Caciana C. Costa $^{1} \&$ Marinês P. Bomfim $^{1}$ \\ ${ }^{1}$ Universidade Federal de Campina Grande/Centro de Ciências e Tecnologia Agroalimentar/Unidade Acadêmica de Ciências Agrárias. Pombal, PB. \\ E-mail: jrar765@gmail.com - ORCID: 0000-0002-1533-3321; jacielagro@hotmail.com - ORCID: 0000-0001-8026-9816; costacc@ccta.ufcg.edu.br \\ (Corresponding author) - ORCID: 0000-0003-2598-466X; mpbfito@gmail.com - ORCID: 0000-0003-2424-3843
}

\begin{abstract}
Green manure is the practice of cultivation and incorporation of plants to the soil, mainly leguminous species, produced or not in situ, for the purpose of preserving and/or restoring soil organic matter and soil nutrients. To compare the effects of incorporating leguminous species in the pre-planting green manure on lettuce production, seven treatments were tested: mineral fertilization; crotalaria (Crotalaria juncea); cowpea (Vigna unguiculata); common bean (Phaseolus vulgaris); lablab bean (Dolichos lablab); pigeon pea (Cajanus cajan) and spontaneous plants. The treatments were arranged in the randomized blocks, with five repetitions. The experiment was conducted in the experimental area of the CCTA/UFCG, in the period from April to December 2016. At 30 days after transplanting, the following variables were analyzed: number of leaves, head diameter, shoot height, root volume, fresh weight of shoots and roots, dry weight of shoots and roots, total fresh weight of shoots and roots, total dry weight of shoots and roots and yield. The results were subjected to analysis of variance and, when significant, Tukey test at 0.05 probability level was applied to compare the means. The results showed that, among the leguminous species, the use of lablab bean led to greater development and yield of lettuce.
\end{abstract}

Key words: Lactuca sativa, nutrient cycling, plant nutrition, yield

\section{Performance agronômica da alface submetida à adubação verde com diferentes espécies leguminosas}

RESUMO: A adubação verde é a prática de cultivo e incorporação de plantas ao solo, principalmente as leguminosas, produzidas no local ou não, com a finalidade de preservação e/ou restauração do teor de matéria orgânica e de nutrientes dos solos. Com o objetivo de comparar os efeitos da incorporação de espécies leguminosas na adubação verde em pré-plantio na produção de alface, foram testados sete tratamentos: Adubação mineral; crotalária (Crotalaria juncea); feijão caupi (Vigna unguiculata); feijãoVagem (Phaseolus vulgaris); labe-labe (Dolichos lablab); feijão guandu (Cajanus cajan) e plantas espontâneas. Os tratamentos foram arranjados no delineamento de blocos casualizados, com cinco repetições. O experimento foi conduzido na área de experimentação do CCTA/UFCG, no período de abril a dezembro de 2016. Aos 30 dias após o transplantio foram analisadas: número de folhas, diâmetro da cabeça, altura da parte aérea, volume de raiz, massa fresca da parte aérea e da raiz, massa seca da parte aérea e da raiz, massa fresca total da parte aérea e da raiz, massa seca total da parte aérea e da raiz e produtividade. Os resultados obtidos foram submetidos à análise de variância, quando significativa foi aplicado nas médias o teste Tukey a 0,05 de probabilidade. Os resultados evidenciaram que entre as leguminosas o emprego da labe-labe proporcionou maior desenvolvimento e produtividade na cultura da alface.

Palavras-chave: Lactuca sativa, ciclagem de nutrientes, nutrição de plantas, produtividade 


\section{INTRODUCTION}

Organic fertilization is important for the productivity of the various existing soils, since it is fertilizer and structuring agent (Batista et al., 2012). It improves physical characteristics, promoting greater water retention, plasticity and porosity, but the supply of nutrients and their actions depend on the material used (Finatto et al., 2013).

Green manure reduces the losses of soil quality, through the recycling of nutrients, promoting better fertility, biological diversity, balance and increase in the yields of crops, stabilizing the production and allowing for a rational and sustainable management (Calegari, 2012). As complementary fertilization, it is an alternative because it reduces the limitations of nutrients, especially nitrogen $(\mathrm{N})$ and the costs with acquisition of inorganic fertilizers (Santos et al., 2014).

Leguminous species can incorporate to the system large amounts of $\mathrm{N}$ through biological fixation (Barradas, 2010), as well as high content of organic material, improving soil structure, protecting it against erosion and promoting rooting distributed in the soil profile (Linhares et al., 2011). In addition, there is an increase in biological $\mathrm{N}$ fixation, balance of $\mathrm{pH}$ and promotion of extraction and mobilization of nutrients in deep soil layers (Fontanétti et al., 2006).

Lettuce is the vegetable which has shown best production responses to $\mathrm{N}$ applications (Filgueira, 2008), and is also a promising crop for systems with introduction of green manure. For that, studies need to be conducted in this context in order to confirm the adoption of this practice due to the beneficial effects on vegetables (Oliveira et al., 2012; Ziech et al., 2014).

This study aimed to evaluate the production performance of lettuce subjected to mineral fertilization and green manure, especially with leguminous species.

\section{Material ANd Methods}

The study was conducted during the period from April to December 2016, at the Center of Sciences and Agrifood Technology (CCTA), of the Federal University of Campina Grande (UFCG), in Pombal, Paraíba, Brazil, a municipality geographically located at longitude $37^{\circ} 48^{\prime} 06^{\prime \prime} \mathrm{W}$ and latitude $6^{\circ} 46^{\prime} 13^{\prime \prime} \mathrm{S}$, at mean altitude of $184 \mathrm{~m}$.

The climate of the municipality, according to Köppen's classification adapted to Brazil (Coelho \& Soncin, 1982), is BS h', which represents a hot and dry climate with summer/ autumn rains and average rainfall of $750 \mathrm{~mm}$ year ${ }^{-1}$. The soil of the experimental area was classified as typic orthic Chromic Luvisol (Brasil, 1972; Santos et al., 2013).

The experiment was conducted in randomized blocks, with seven treatments and five replicates, totaling 35 plots. Treatments were: T1- Mineral fertilization; T2-Crotalaria (Crotalaria juncea); T3- Cowpea (Vigna unguiculata); T4- Common bean
(Phaseolus vulgaris); T5- Lablab bean (Dolichos lablab); T6Pigeon pea (Cajanus cajan) and T7-Spontanous vegetation (control). Each plot was $1.2 \times 1.2 \mathrm{~m}$, with total area of $1.44 \mathrm{~m}^{2}$.

Soil tillage consisted of plowing to $20 \mathrm{~cm}$ depth, and after that the beds were manually raised $(0.30 \mathrm{~m}$ high). Soil samples were collected for physical and chemical analyses prior to the experiment (Table 1).

According to the expected cycle, the leguminous species were sown on different days (Table 2), in order to be incorporated on a single day. Three seeds were planted per hole and thinning was performed one week after emergence of plants.

Spontaneous vegetation in the plots with leguminous species was manually controlled by weeding with a small hoe on the bed and a hoe in interrows. The control plot was incorporated only with spontaneous vegetation, which was allowed to grow freely.

No pests or diseases were observed and, therefore, phytosanitary control was not necessary. The irrigation system used in the area was micro-sprinkler with flow rate of $80 \mathrm{~mm} \mathrm{~h}^{-1}$, and irrigation was applied twice a day with duration of approximately $20 \mathrm{~min}$ in each event. Leguminous species were incorporated to the soil when they reached maximum vegetative growth, i.e., beginning of flowering.

The plants used have different cycles and, therefore, it was necessary to elaborate a schedule so that all plants were at maximum vegetative growth on the date of incorporation. On the day of incorporation, these plants were mowed at soil level, ground using a grinding machine with $12-\mathrm{mm}$ blade and incorporated to the $0-10 \mathrm{~cm}$ soil layer.

Samples of each crop were also collected for analysis of plant material, fully expanded and healthy leaves, in order to know their nutritional composition (Table 3). At 75 days after incorporating green manure crops, the plots were prepared by raising a $30-\mathrm{cm}$-high layer for lettuce cultivation.

Lettuce was grown from seedlings produced on expanded polystyrene trays of 200 cells, filled with commercial substrate Hortplant $^{\oplus}$, by planting two seeds per cell. At 10 days after emergence, thinning was performed to leave only one plant per cell.

The lettuce cultivar used in the experiment was 'Babá de Verão', belonging to the 'Loose/broad-leaved' group with soft, smooth and loose leaves, without formation of head and with light green color (Filgueira, 2008).

Table 2. Sowing date, spacing and cycle until flowering of the leguminous species with potential for green manure

\begin{tabular}{lccc}
\multicolumn{1}{c}{ Species } & $\begin{array}{c}\text { Sowing } \\
\text { data }\end{array}$ & $\begin{array}{c}\text { Spacing } \\
(\mathbf{m})\end{array}$ & $\begin{array}{c}\text { Cycle until beginning } \\
\text { of flowering }\end{array}$ \\
Lablab bean & April 14, 2016 & $0.50 \times 0.15$ & 120 days \\
Crotalaria & May 04, 2016 & $0.50 \times 0.35$ & 100 days \\
Common bean & May 24, 2016 & $1.00 \times 0.50$ & 75 days \\
Cowpea & May 24, 2016 & $0.80 \times 0.30$ & 75 days \\
Pigeon pea & May 24, 2016 & $0.50 \times 0.50$ & 75 days \\
\hline
\end{tabular}

Table 1. Chemical analysis of the soil of the experimental area

\begin{tabular}{|c|c|c|c|c|c|c|c|c|c|c|}
\hline \multirow{2}{*}{$\begin{array}{l}\text { Depth } \\
\text { (cm) }\end{array}$} & pH & OM & $\mathbf{P}$ & $\mathrm{K}^{+}$ & $\mathrm{Na}^{+}$ & $\mathrm{Ca}^{2+}$ & $\mathrm{Mg}$ & Al & $\mathrm{H}+\mathrm{Al}$ & SB \\
\hline & $\begin{array}{c}\mathrm{H}_{2} \mathrm{O} \\
1: 2.5\end{array}$ & \multicolumn{2}{|c|}{$\left(\mathrm{mg} \mathrm{dm} \mathrm{m}^{-3}\right)$} & \multicolumn{7}{|c|}{$\left(\mathrm{cmol}_{\mathrm{c}} \mathrm{dm}^{-3}\right)$} \\
\hline 20 & 7.70 & 28.38 & 675 & 0.68 & 0.08 & 7.60 & 3.80 & 0.00 & 0.00 & 12.16 \\
\hline
\end{tabular}

OM - Organic matter; Walkley-Black Wet Digestion; P, K, Na - Extracted with Mehlich 1; Ca, Mg, Al - Extracted with $1 \mathrm{M} \mathrm{KCl;} \mathrm{H} \mathrm{+} \mathrm{Al} \mathrm{-} \mathrm{Extracted} \mathrm{with} 0.5 \mathrm{M}$ calcium acetate; SB - Sum of bases 
Table 3. Nutritional analysis of the plant tissues of the crops with potential for green manure

\begin{tabular}{lccr} 
& $\mathbf{N}$ & $\mathbf{P}$ & $\mathbf{K}$ \\
\cline { 2 - 4 } & & $(\mathbf{g ~ k g}$ & \\
Lablab bean & 46.73 & 6.45 & 17.60 \\
Crotalaria & 42.18 & 5.08 & 11.28 \\
Cowpea & 40.25 & 4.19 & 14.85 \\
Pigeon pea & 38.85 & 5.99 & 9.35 \\
Common bean & 29.93 & 5.33 & 11.83 \\
\hline
\end{tabular}

Analysis conducted at the Laboratory of Analysis of Soil, Water and Plan of the IFPB-Campus Sousa. 2016

For the plot with mineral fertilization, a top-dressing fertilization was performed 5 days after transplanting, applying $30 \mathrm{~kg} \mathrm{ha}^{-1} \mathrm{~N}$ and $90 \mathrm{~kg} \mathrm{ha}^{-1}$ of $\mathrm{K}$, as recommended by Filgueira (2008). Weeding was performed by hand to eliminate weeds as soon as they appeared. No phytosanitary treatment was conducted, since there was no attack of diseases and pests.

Lettuce was harvested 30 days after transplanting, when plants reached maximum vegetative development. The characteristics evaluated in lettuce were shoot height, head diameter, number of leaves, root volume, fresh weight of shoots and roots, dry weight of shoots and roots, total fresh weight of shoots and roots, total dry weight of shoots and roots and yield. For soil characteristics, the variations of chemical and nutritional attributes were evaluated along the whole experiment.

The collected data were subjected to analysis of variance by $\mathrm{F}$ test and means were compared by Tukey test, both at 0.05 probability level for lettuce using the program SISVAR, version 5.6 (Ferreira, 2011).

\section{Results AND Discussion}

By analyzing the number of leaves in lettuce plants (Table 4), it was observed that mineral fertilization and green manure with Crotalaria, Cowpea, Common bean and Pigeon pea did not differ. Lablab bean stood out for leading to highest increment in the production of lettuce leaves.

This accumulation in the photosynthetic apparatus was possibly due to greater amount of organic matter left by this leguminous species in the soil, according to the analyses conducted at the end of lettuce cultivation (Santos et al., 2016).

Studying green manure in organic production of lettuce, using velvet bean (Mucuna pruriens (L.) DC), jack bean (Canavalia ensiformis (L.) DC.), crotalaria (Crotalaria spectabilis Roth), dwarf pigeon pea (Cajanus cajan cv. Iapar 43) and spontaneous vegetation, Bento et al. (2015) found for the number of marketable leaves that the highest mean was observed using pigeon pea, which differed from spontaneous vegetation.

Compared to pigeon pea, the lablab bean led to increase of $27.3 \%$ for this same variable. Among the leguminous species, lablab bean was the one that stood out with respect to the characteristics evaluated. Coelho et al. (2011) observed that the number of lettuce leaves was higher when plants were subjected to pre-cultivation of leguminous species, compared to fallow soil with spontaneous vegetation. This fact can also be observed in the present study.

For head diameter, shoot height and root volume of lettuce as a function of the leguminous crops used (Table 4), the means were 25.51, 17.13 and 22.17, respectively. However, these variables did not have direct relation with production parameters since the incorporation of green manure crops led to plants with higher number of leaves (NL) and higher accumulation of fresh and dry weight (Tables 4 and 5).

For shoot fresh weight (SFW) and root fresh weight (RFW), there were significant increments between most of

Table 4. Number of leaves (NL), head diameter (HD), shoot height (SH), root volume (RV), shoot fresh weight (SFW) and root fresh weight (RFW) as a function of the evaluation of leguminous species with potential for green manure in lettuce cultivation

\begin{tabular}{|c|c|c|c|c|c|c|}
\hline \multirow{2}{*}{ Treatment } & \multirow{2}{*}{ NL } & HD & SH & \multirow{2}{*}{$\begin{array}{c}\mathrm{RV} \\
(\mathrm{mL})\end{array}$} & SFW & RFW \\
\hline & & & & & \multicolumn{2}{|c|}{ (g) } \\
\hline $\mathrm{T} 1$ & $13.92 \mathrm{ab}$ & $23.97 \mathrm{a}$ & $16.97 \mathrm{a}$ & $21.09 \mathrm{a}$ & $124.80 \mathrm{~b}$ & $13.60 \mathrm{~d}$ \\
\hline T2 & $13.80 a b$ & $27.31 \mathrm{a}$ & $18.10 \mathrm{a}$ & $21.10 \mathrm{a}$ & $118.40 \mathrm{~b}$ & $11.80 \mathrm{e}$ \\
\hline T3 & $15.82 \mathrm{ab}$ & $25.47 \mathrm{a}$ & $17.84 \mathrm{a}$ & $24.99 \mathrm{a}$ & $113.40 \mathrm{bc}$ & $15.40 \mathrm{bc}$ \\
\hline T4 & $14.38 a b$ & $23.84 \mathrm{a}$ & $16.17 \mathrm{a}$ & $21.65 \mathrm{a}$ & $122.00 \mathrm{~b}$ & $14.20 \mathrm{~cd}$ \\
\hline T5 & $18.18 \mathrm{a}$ & $29.32 \mathrm{a}$ & $18.60 \mathrm{a}$ & $24.99 \mathrm{a}$ & $213.00 \mathrm{a}$ & $19.60 \mathrm{a}$ \\
\hline T6 & $14.28 \mathrm{ab}$ & $23.87 \mathrm{a}$ & $16.20 \mathrm{a}$ & $21.93 \mathrm{a}$ & $107.20 \mathrm{bc}$ & $16.00 \mathrm{~b}$ \\
\hline $\mathrm{T} 7$ & 11.88 b & $24.80 \mathrm{a}$ & $16.02 \mathrm{a}$ & $19.42 \mathrm{a}$ & 94.20 c & $10.20 \mathrm{f}$ \\
\hline LSD & 5.17 & 9.51 & 6.30 & 8.50 & 20.74 & 1.62 \\
\hline
\end{tabular}

Means followed by the same lowercase letter, for each variable evaluated, do not differ by Tukey test at 0.05 probability level; T1 - Mineral fertilization; T2 - Crotalaria (Crotalaria juncea); T3 - Cowpea (Vigna unguiculata); T4 - Common bean (Phaseolus vulgaris); T5 -Lablab bean (Dolichos lablab); T6 - Pigeon pea (Cajanus cajan); T7 - Spontaneous vegetation (control); LSD - Least significant difference

Table 5. Total fresh weight (TFW), shoot dry weight (SDW), root dry weight (RDW), total dry weight (TDW) and yield (Y) of lettuce as a function of the evaluation of leguminous species with potential for green manure in lettuce cultivation

\begin{tabular}{|c|c|c|c|c|c|}
\hline \multirow{2}{*}{ Treatment } & TFW & SDW & RDW & TDW & \multirow{2}{*}{$\begin{array}{c}Y \\
\left(t \mathrm{ha}^{-1}\right)\end{array}$} \\
\hline & \multicolumn{4}{|c|}{ (g) } & \\
\hline $\mathrm{T} 1$ & $138.40 \mathrm{~b}$ & $6.01 \mathrm{c}$ & $0.95 \mathrm{~cd}$ & $6.96 \mathrm{c}$ & $16.57 \mathrm{~b}$ \\
\hline T2 & $130.20 b$ & $7.88 \mathrm{ab}$ & $0.89 \mathrm{~cd}$ & $8.77 \mathrm{~b}$ & $15.62 \mathrm{~b}$ \\
\hline T3 & $155.80 \mathrm{~b}$ & $8.15 a b$ & $0.99 \mathrm{bc}$ & $9.15 b$ & 14.78 b \\
\hline T4 & $136.20 \mathrm{~b}$ & $7.46 a b$ & $1.14 \mathrm{~b}$ & $8.60 \mathrm{~b}$ & $16.34 \mathrm{~b}$ \\
\hline T5 & $232.20 \mathrm{~b}$ & $10.75 \mathrm{a}$ & $1.28 \mathrm{a}$ & $12.06 \mathrm{a}$ & $27.91 \mathrm{a}$ \\
\hline T6 & $123.60 \mathrm{a}$ & $7.38 a b$ & $1.12 b$ & $8.50 \mathrm{~b}$ & $14.78 \mathrm{bc}$ \\
\hline $\mathrm{T} 7$ & $104.22 \mathrm{C}$ & $5.30 \mathrm{~d}$ & $0.83 d$ & $6.13 c$ & $12.50 \mathrm{C}$ \\
\hline LSD & 20.36 & 1.0 & 0.16 & 1.11 & 2.5 \\
\hline
\end{tabular}

Means followed by the same lowercase letter, for each variable evaluated, do not differ by Tukey test at 0.05 probability level; T1 - Mineral fertilization; T2 - Crotalaria (Crotalaria juncea); T3 - Cowpea (Vigna unguiculata); T4 - Common bean (Phaseolus vulgaris); T5 -Lablab bean (Dolichos lablab); T6 - Pigeon pea (Cajanus cajan); T7 - Spontaneous vegetation (control); LSD - Least significant difference 
the leguminous species used and the spontaneous vegetation (Table 4), resulting in increases of up to 48.87 and $55.77 \%$ for RFW and SFW, respectively.

For shoot dry weight (SDW), root dry weight (RDW) and total dry weight (TDW) of lettuce, significant difference was observed between lettuce plants grown with pre-cultivation of leguminous species and those which received mineral fertilization (Table 5), obtaining the respective highest values of $10.75,1.28$ and $12.06 \mathrm{~g}$ in the plots under green manure with lablab bean (Dolichos lablab).

These results evidenced increments of $102 \%$ in SDW, $54.2 \%$ in RDW and $96.7 \%$ in TDW in relation to the treatment subjected to incorporation of spontaneous vegetation. Compared with the mineral fertilization, there were increases of $78.8,34.7$ and $73.3 \%$, respectively.

This fact can be explained possibly by the quantity $\mathrm{N}$ (46.73 $\left.\mathrm{g} \mathrm{kg}^{-1}\right), \mathrm{P}\left(6.45 \mathrm{~g} \mathrm{~kg}^{-1}\right)$ and $\mathrm{K}\left(17.6 \mathrm{~g} \mathrm{~kg}^{-1}\right)$ present in the lablab bean biomass incorporated to the soil (Table 3 ) and its nutrient recycling capacity, corroborated with the $\mathrm{N}$ content and the increase in cation exchange capacity, sum of bases and soil organic matter (Santos et al., 2016).

Teodoro et al. (2011), studying the agronomic aspects of leguminous crops for green manure in the Jequitinhonha valley, observed that there are significant differences in terms of quantity of nutrients accumulated in the dry matter of these species, so that the amount of $\mathrm{N}$ accumulated depends on the species used.

According to Faria et al. (2007), incorporation of plants with high biomass production, rich in nutrients, to the soil can improve its physical, chemical and biological properties, besides allowing the conservation or increase of fertility, which may justify the fact observed for these characteristics, since the improvement of the soil directly contributes to a high production of crops.

According to Formentini et al. (2008), lablab bean incorporates 4 to $6 \mathrm{tha}^{-1}$ of dry matter, providing a $\mathrm{N}$ supply to the lettuce crop of 120 to $240 \mathrm{~kg} \mathrm{ha}^{-1}$. Table 5 shows, for SDW, that the treatments with crotalaria, cowpea, common bean, pigeon bean and lablab bean were similar to one another, but differed from both mineral fertilization and spontaneous vegetation.

Partially similar results were obtained by Fontanétti et al. (2006), evaluating green manure in organic production of lettuce. These authors found that crotalaria had a much higher production of shoot phytomass than that of spontaneous vegetation, expressively contributing to the $\mathrm{N}$ supply in the system.

Green manure with lablab bean led to yield of $27.9 \mathrm{t} \mathrm{ha}^{-1}$ and a lower value was found in plots subjected to treatment with spontaneous vegetation. The comparison between plants of treatments with leguminous species and those under incorporation of spontaneous vegetation showed that all leguminous crops increased lettuce yield, except the pigeon pea.

This result is similar to those found by Cavalcante et al. (2015), who studied the production of green manure crops and the use of residues in chives and observed that the spontaneous vegetation showed low dry matter production, which consequently led to lower yield. Unlike mineral fertilization, the use of leguminous species, besides supplying essential elements to plant development, improves the physical and biological conditions of the soil, and this degree of improvement will depend on the management adopted and on the species used (Filgueira, 2008).

These factors can explain these results for the evaluated characteristics in plants subjected to green manure with lablab bean, compared to those grown with mineral fertilizer, or even those grown with other leguminous crops, because these characteristics change according to species and management adopted.

\section{Conclusions}

1. Lablab bean promotes highest biomass production in the lettuce crop.

2. The leguminous species, common bean cowpea, pigeon pea and crotalaria lead to lettuce yields close to those obtained with mineral fertilization.

\section{Literature Cited}

Barradas, C. A. A. Uso da adubação verde. Niterói: Programa rio rural, 2010. 10p. Manual Técnico, 25

Batista, M. A. V.; Vieira, L. A.; Souza, J. P.; Freitas, J. D. B.; Bezerra Neto, F. Efeito de diferentes fontes de adubação sobre a produção de alface no município de Iguatu-CE. Revista Caatinga, v.25, p.8-11, 2012.

Bento, T. S.; Carvalho, M. A. C.; Gervazio, W. Adubação verde e sistema de cultivo na produção orgânica de alface. Cadernos de Agroecologia, v.9, p.1-12, 2015.

Brasil. Ministério da Agricultura, Pecuária e Abastecimento. Levantamento exploratório: Reconhecimento de solos do Estado da Paraíba. Rio de Janeiro: MAPA, 1972. 670p.

Calegari, A. Plantas de cobertura em sistema Plantio direto de qualidade (SPDq). Revista A Granja, v.68, p.67-69, 2012.

Cavalcante, V. S.; Barboza, J. T. V.; Costa, L. C.; Santos, V. R.; Santos, M. J. N. Produção de adubos verdes e a utilização dos resíduos no cultivo da cebolinha. Revista Brasileira de Agroecologia, v.10, p.24-31, 2015.

Coelho, A. A.; Silva, G. L. da; Queiroga, M. B. de A.; Augusto, J.; Virgínio, J. P.; Pôrto, D. R. de Q. Efeitos da adubação verde, na forma de pré-cultivo, na produção de diferentes cultivares de alface sob manejo agroecológico. Cadernos de Agroecologia, v.6, p.1-6, 2011.

Coelho, M. A.; Soncin, N. B. Geografia do Brasil. São Paulo: Moderna, 1982.368p.

Faria, C. M. B.; Costa, N. D.; Faria, A. F. Atributos químicos de um argissolo e rendimento de melão mediante o uso de adubos verdes, calagem e adubação. Revista Brasileira de Ciências do Solo, v.31, p.299-307, 2007. https://doi.org/10.1590/S010006832007000200012

Ferreira, D. F. Sisvar: A computer statistical analysis system. Ciência e Agrotecnologia, v.35, p.1039-1042, 2011. https://doi.org/10.1590/ S1413-70542011000600001

Filgueira, F. A. R. Novo manual de olericultura: Agrotecnologia moderna na produção e comercialização de hortaliças. 3.ed. Viçosa: UFV, 2008. 412p. 
Finatto, J.; Altmayer, T.; Martini, M. C.; Rodrigues, M.; Basso, V.; Hoehne, L. A importância da utilização da adubação orgânica na agricultura. Revista Destaques Acadêmicos, v.5, p.85-93, 2013.

Fontanétti, A.; Carvalho, G. J. de; Gomes, L. A. A.; Almeida, K. de; Moraes, S. R. G. de; Teixeira, C. M. Adubação verde na produção orgânica de alface americana e repolho. Horticultura Brasileira, v.24, p.146-150, 2006. https://doi.org/10.1590/S0102-05362006000200004

Formentini, E. A.; Lóss, F. R.; Bayerl, M. P.; Lovati, R. D.; Baptista, E. Cartilha sobre adubação verde e compostagem. Vitória: Incaper, 2008. 27p.

Linhares, P. C. F.; Mendonça, J. D. J.; Maracajá, P. B.; Pereira, M. F. S.; Paz, A. E. S. Cultivo de coentro sob efeito residual de diferentes doses de jitirana. Revista Verde de Agroecologiae Desenvolvimento Sustentável, v.6, p.109-114, 2011.

Oliveira, L. B.; Stangarlin, J. R.; Lana, M. C.; Simon, D. N.; Zimmermann, A. Influência de adubações e manejo de adubo verde nos atributosbiológicos de solo cultivado com alface (Lactuca sativa L.) em sistema de cultivo orgânico. Arquivo Instituto Biologia, v.79, p.557-565, 2012. https://doi.org/10.1590/S1808-16572012000400013

Santos, H. G.; Jacomine, P. K. T.; Anjos, L. H. C.; Oliveira, V. A.; Oliveira, J. B.; Coelho, M. R.; Lumbreras, J. F.; Cunha, T. J. F. (eds.). Sistema brasileiro de classificação de solos. 3.ed. Rio de Janeiro: Embrapa Solos, 2013. 353p.
Santos, J. J. F. dos; Costa, C. C.; Sarmento, J. J. A.; Cartaxo, T. L. Efeito da incorporação da adubação verde em diferentes épocas com espécies leguminosas sobre as propriedades químicas do solo. In: Seabra, G. (org.). Educação ambiental: O capital natural na economia global. 1.ed. Ituiutaba: Editora Barlavento, 2016. p.1682-1691.

Santos, R. A.; Carneiro, P. T.; Santos, V. R.; Costa, L. C.; Santos, C. G.; Santos Neto, A. L. Crescimento de leguminosas utilizadas na adubação verde em diferentes níveis de sais na água de irrigação. Revista Brasileira de Engenharia Agrícola e Ambiental, v.18, p.1255-1261, 2014. https://doi.org/10.1590/1807-1929/agriambi. v18n12p1255-1261

Teodoro, R. B.; Oliveira, F. L. de; Silva, D. M. N. da; Fávero, C.; Quaresma, M. A. L. Aspectos agronômicos de leguminosas para Adubação verde no cerrado do alto vale do Jequitinhonha. Revista Brasileira de Ciência do Solo, v.35, p.635-643, 2011. https://doi. org/10.1590/S0100-06832011000200032

Ziech, A. R. D.; Conceição, P. C.; Luchese, A. V.; Paulus, D.; Ziech, M. F. Cultivo de alface em diferentes manejos de cobertura do solo e fontes de adubação. Revista Brasileira de Engenharia Agrícola e Ambiental, v.18, p.948-954, 2014. https://doi.org/10.1590/18071929/agriambi.v18n09p948-954 